\title{
Management of Fusarium Wilt of Castor (Ricinus communis L.) Caused by Fusarium oxysporum f. sp. ricini with Antagonist, Botanical Extract and Pot Experiment
}

\author{
B. Vahunia ${ }^{1 *}$, P. Singh ${ }^{2}$, N.Y. Patel ${ }^{1}$ and A. Rathava ${ }^{1}$ \\ ${ }^{1}$ Department of Plant Pathology, N. M. College of Agriculture, Navsari Agricultural University, \\ Navsari, Gujarat, India \\ ${ }^{2}$ Department of Plant Pathology, Aspee Shakilam Agri Biotechnology Institute, Nau, Navsari, \\ Gujarat, India \\ *Corresponding author
}

\section{A B S T R A C T}

\begin{tabular}{|l|}
\hline Ke y w o r d s \\
Castor wilt, \\
$\begin{array}{l}\text { Fusarium } \\
\text { oxysporum f. sp. } \\
\text { ricini, Antagonist, } \\
\text { Botanical extract, } \\
\text { in vitro. }\end{array}$ \\
\hline Article Info \\
\hline $\begin{array}{l}\text { Accepted: } \\
\text { 04 July } 2017 \\
\text { Available Online: } \\
\text { 10 September } 2017\end{array}$ \\
\hline
\end{tabular}

Keywords

Castor wilt,

oxysporum f. sp.

ricini, Antagonist

Botanical extract,

in vitro.

Article Info

10 September 2017
The bioefficacy of antagonist and botanical extract were tested in vitro against Fusarium oxysporum f. sp. ricini causing wilt of castor. Trichoderma harzianum (72.22\%), T. viride (70.37\%) and Pseudomonas fluorescens appeared potent antagonist against Fusarium oxysporum f. sp. ricini followed by $T$. faciculatum, $T$. longibrachyatum and Bacillus subtilis. Among the botanical, the extract of turmeric rhizome was effective in inhibiting mycelial growth 42.22 Per cent followed by 36.67 per cent inhibition by leaves extract of marigold. Pot culture experiment conducted at Department of Plant Pathology, College of Agriculture, Navsari. Antagonists and botanical extract which were found promising in in vitro study were tested in pot culture experiment. Result revealed that seed treatment with Trichoderma harzianum found superior in control of Fusarium oxysporum $\mathrm{f}$. sp. ricini causing wilt of castor.

\section{Introduction}

Castor (Ricinus communis L.) is one of the most important non-edible oilseed crops of arid and semi-arid regions of India. It belongs to genus Ricinus of Euphorbiaceae family and its common name is castor bean, other common names include castor-oil plant and palmachristi. In Gujarat (India), castor seed is grown over an area of 7.34 lakh hectares with the production of 13.95 lakh tones (Anonymous, 2015). It is attacked by several pathogens, viz., fungi, bacteria, viruses, nematodes and phytoplasmas. The important fungal diseases are Phytophthora seedling blight, Rust, Alternaria leaf spot, Cercospora leaf spot, Anthracnose, Powdery Mildew, Stem rot, and Fusarium wilt. Important bacterial diseases are Bacterial leaf spot, Bacterial wilt or Slime disease and viral diseases are like Tobacco ring spot, Tobacco necrosis and cucumber mosaic virus. Among these, the wilt is one of the major constraints and known to cause heavy losses due to occurrence of frequent epidemic in intensive castor growing area of Gujarat. Therefore, 
effort were made to find out the cheap, effective, eco-friendly, botanical and bioagents by testing in vitro against Fusarium oxysporum f. sp. ricini from these effective can be later on tested in pot condition.

\section{Materials and Methods}

\section{Experimental location}

This work was conducted in Department of Plant Pathology, N. M. College of Agriculture, Navsari agricultural University, Navsari during 2015-16. Determine the antifungal activity of Trichoderma viride, $T$. harzianum, T. longibrachyatum, T. koningii, T. fasciculatum, Pseudomonas fluorescens and Bacillus subtilis against Fusarium oxysporum f. sp. ricini by dual culture technique (Skidmore and Dickinson, 1976).

\section{Evaluation of antagonistic potentiality of bioagentin vitro}

The test organisms and pathogen were grown separately on PDA. From seven day old culture, $4 \mathrm{~mm}$ discs of the test organisms and Fusarium oxysporum f. sp. ricini were cut aseptically from the periphery of the colony and placed opposite to each other approximately $60 \mathrm{~mm}$ apart on to PDA contained in the Petri plates as adopted by Dennis and Webster (1971).To determine the antagonistic action of isolates of bacterial species viz., Bacillus subtilis and Pseudomonas fluorescence against Fusarium oxysporum f. sp. Ricini in vitro. The bacterial antagonists were then streaked on one end of the Petri plate onto PDA medium 24 hrs. Prior to Fusarium oxysporum f. sp. ricini inoculation and just opposite to bacterial streak a $4 \mathrm{~mm}$ diameter disc of Fusarium oxysporum f. sp. ricini from seven days old culture was placed. Three repetitions of each treatment were kept and the Petri plates with $4 \mathrm{~mm}$ diameter discs of 7 days old culture of the pathogen on PDA served as control. The
Petri plates were incubated at $27 \pm 2^{\circ} \mathrm{C}$ temperature and after seven days of incubation, radial growth of the test organism and the Fusarium oxysporum f. sp. ricini was measured. Per cent growth inhibition of the fungus in each treatment in comparison to control was calculated by the following equation (Bliss, 1934):

PGI $=\frac{\mathrm{C}-\mathrm{T}}{\mathrm{C}}$

Where,

PGI $=$ Per cent growth inhibition

$\mathrm{C}=$ Colony diameter in control $(\mathrm{mm})$

$\mathrm{T}=$ Colony diameter in treatment $(\mathrm{mm})$

Efficacy of botanicals against Fusarium oxysporum f. sp. ricini

Extract of plants tested against castor wilt pathogen Fusarium oxysporum f. sp. ricini were, leaves of Bougainvillea spectablis L., Datura stramonium L., Ocimum sanctum L., Hibiscus bombycideron, Tegateserecta., rhizome of Zingiberofficinale Rosc., Curcuma longa L. (Table 2). Solvents i.e. distilled water was employed for extraction from plant parts and results were derived based on comparative toxicity value. Different parts of plants including leaf and rhizome tested were first washed with sterile distilled water, then sterilized with 90 per cent methanol and then air-dried. Weighed $100 \mathrm{~g}$ plant material was crushed in electrically operated mixer and grinder using 1:1 w/v amount of distilled water (Singh and Majumdar, 2001).

The material was homogenized for 5 minutes and filtered through double layered muslin cloth and filtrate was centrifuged at $5000 \mathrm{rpm}$ for 15 minutes and clear supernatant was collected. This was considered as 100 per cent concentration and used for experiment at various percentages. 
For evaluation of antifungal activities of the extract, desired concentrations $(5 \%)$ were obtained by adding appropriate amount of standard solution of plant extracts to $100 \mathrm{ml}$ potato dextrose agar medium in conical flasks. Then about $20 \mathrm{ml}$ extract mixed PDA was poured in sterilized Petri plates. After, solidification of PDA, plates was inoculated with $4 \mathrm{~mm}$ diameter discs of seven days old culture of Fusarium oxysporum f. sp. ricini raised on PDA medium. Each treatment was repeated three times. PDA inoculated with 4 $\mathrm{mm}$ fungal discs without plant extract served as control. The inoculated plates were incubated at $27 \pm 2^{\circ} \mathrm{C}$ for 7 days and diameter of colony was measured.

The per cent growth inhibition of the fungus in each treatment in comparison with control was calculated by the equation given by Bliss, 1934 as mentioned earlier.

\section{Management of wilt under pot condition}

The antagonists and botanicals which found promising in vitro study were tested for the control of castor wilt in pots as seed treatment.

The inoculum of Fusarium oxysporum f. sp. ricini was multiplied on sand maize meal medium for 20 days at $27 \pm 2^{\circ} \mathrm{C}$ and thoroughly mixed with the sterilized soil in proportion of 1:10 w/w, and then filled in the sterilized pots. The pots were watered and kept for a week for uniform spread of the pathogen. The formulation of each two promising bioagent@ 6g/kg seed and botanicals was prepared. The seeds of castor variety were treated with the botanicals and bioagent@6g/kg seed formulation. Seeds sown without treatment in the inoculated pots served as control.

Treated seeds of castor hybrid GCH-4 were sown in each pot. Untreated seeds were sown in inoculated pots served as control. Three repetitions were maintained for each treatment. They were uniformly irrigated soon after seed sowing. Observation on wilt incidence was recorded periodically up to 30 days after sowing and data were statistically analysed.

\section{Result and Discussion}

\section{In vitro testing of antagonists against Fusarium oxysporum f. sp. ricini}

The result presented in table 1 and figure 1 revelled that, Trichoderma harzianum (72.22\%), Trichoderma viride (70.37\%), Pseudomonas fluroscens (67.78\%), Trichoderma longibrachytum (64.44\%) and Trichoderma koningi (62.96\%) significantly inhibited the pathogen.

Whereas, Trichoderma faciculatum (55.19\%) and Bacillus subtilis (45.19\%) were comparatively least effective.

Our result are in harmony with earlier workers Meghwal et al., (2014) found that $T$. harzianum and $T$. viride significantly inhibited the mycelial growth of Fusarium oxysporum f. sp. ricini $(68-72 \%)$ by Dual culture technique. Patil et al., (2015) carried out interaction study of known antagonist by dual culture method and found strong antagonistic effect on Fusarium oxysporum f. sp. ciceri with $T$. viride, T. koningii, G. virens, T. pseudokoningii and Pseudomonas fluroscensin vitro.

In vitro testing of botanicals against Fusarium oxysporum f. sp. ricini

The result presented in table 2 revealed that, turmeric rhizome extract (Curcuma longa L.) 42.22 per cent showed maximum growth inhibition of the pathogen followed by marigold leaves (Tegetes erecta L.) 36.67 per 
cent, Tulsi leaves (Ocimum sanctum L.) 34.44 per cent, Bougainvillea leaves (Bougainvellea spectabilis L.) 31.85 per cent, Jasud leaves (Hibiscus bombycideron L.) 30.74 per cent,
Ginger (Zingiber officinalis Rosa.) 25.93 per cent and Datura (Datura stramonium L.) 18.89 per cent in sterilized plant extract (Fig. 2).

Table.1 Efficacy of native bio-agent against Fusarium oxysporum f. sp. ricini in vitro

\begin{tabular}{|c|l|c|c|}
\hline $\begin{array}{c}\text { Sr. } \\
\text { No. }\end{array}$ & \multicolumn{1}{|c|}{ Test organism } & $\begin{array}{l}\text { Colony diameter } \\
\text { of pathogen }(\mathbf{m m})\end{array}$ & $\begin{array}{l}\text { Growth inhibition } \\
\text { over control }(\%)\end{array}$ \\
\hline 1 & Trichoderma virideNavsari isolate & 26.67 & 70.37 \\
\hline 2 & Trichoderma harzianum Navsari isolate & 25.00 & 72.22 \\
\hline 3 & Trichoderma longibrachyatumNavsari isolate & 32.00 & 64.44 \\
\hline 4 & Trichoderma koningiNavsari isolate & 33.33 & 62.96 \\
\hline 5 & Trichoderma faciculatumNavsari isolate & 40.33 & 55.19 \\
\hline 6 & Pseudomonas fluorescens Navsari isolate & 29.00 & 67.78 \\
\hline 7 & Bacillus subtilis Navsari isolate & 49.33 & 45.19 \\
\hline 8 & Control & 90.00 & 0.00 \\
\hline \multirow{2}{*}{} & S.Em. \pm & 0.99 & \\
\cline { 2 - 3 } & C.D. at 5\% & 2.96 & \\
\cline { 2 - 3 } & C.V.\% & 4.20 & \\
\hline
\end{tabular}

Table.2 Efficacy of botanicals against Fusarium oxysporum f. sp. ricini in vitro

\begin{tabular}{|c|l|l|l|l|c|}
\hline $\begin{array}{l}\text { Sr. } \\
\text { No. }\end{array}$ & $\begin{array}{l}\text { Name of } \\
\text { plant }\end{array}$ & Botanicals name (5\%) & $\begin{array}{l}\text { Plant parts } \\
\text { used for } \\
\text { preparation of } \\
\text { extract }\end{array}$ & $\begin{array}{l}\text { Average colony } \\
\text { diameter of } \\
\text { pathogen (mm) }\end{array}$ & $\begin{array}{l}\text { Growth } \\
\text { inhibition } \\
\text { over control } \\
(\mathbf{\%})\end{array}$ \\
\hline 1 & Bougainvillea & $\begin{array}{l}\text { Bougainvillea } \\
\text { spectabilis L. }\end{array}$ & Leaves & 58.33 & 31.85 \\
\hline 2 & Ginger & Zingiber officinalis L. & Rhizome & 63.67 & 25.92 \\
\hline 3 & Datura & Datura stramonium L. & Leaves & 70.00 & 18.89 \\
\hline 4 & Turmeric & Curcuma longa L. & Rhizome & 49.00 & 42.22 \\
\hline 5 & Tulsi & Ocimum sanctum L. & Leavs & 56.00 & 34.44 \\
\hline 6 & Jasud & Hibiscus bombycideron & Leaves & 59.33 & 30.74 \\
\hline 7 & Marigold & Tegeteserecta & Leaves & 54.00 & 36.67 \\
\hline 8 & Control & $\ldots \ldots$ & $\ldots \ldots$ & 87.00 & 0.00 \\
\hline & S.Em. \pm & & & 1.32 & \\
\cline { 2 - 6 } & C.D. at $5 \%$ & & & 3.97 & \\
\cline { 2 - 6 } & C.V.\% $\%$ & & & 3.69 & \\
\hline
\end{tabular}

Table.3 Management of wilt under pot condition

\begin{tabular}{|c|l|c|c|c|}
\hline Sr. No. & \multicolumn{1}{|c|}{ Treatment } & $\begin{array}{c}\text { Average no. of } \\
\text { plant infected }\end{array}$ & $\begin{array}{c}\text { Percent disease } \\
\text { incidence }\end{array}$ & $\begin{array}{c}\text { Percent disease reduction } \\
\text { over control }\end{array}$ \\
\hline 1 & Trichoderma viride Navsari isolate & 2.67 & 26.67 & 62.92 \\
\hline 2 & Trichoderma harzianum Navsari isolate & 2.33 & 23.33 & 70.83 \\
\hline 3 & Turmeric & 3.33 & 33.33 & 58.33 \\
\hline 4 & Marigold & 3.67 & 36.67 & 54.17 \\
\hline 5 & Control & 8.00 & 80.00 & 0.00 \\
\hline \multirow{2}{*}{} & S.Em. \pm & 0.21 & & \\
\cline { 2 - 5 } & C.D. at 5\% & 0.69 & & \\
\cline { 2 - 5 } & C.V.\% & 9.13 & & \\
\hline
\end{tabular}



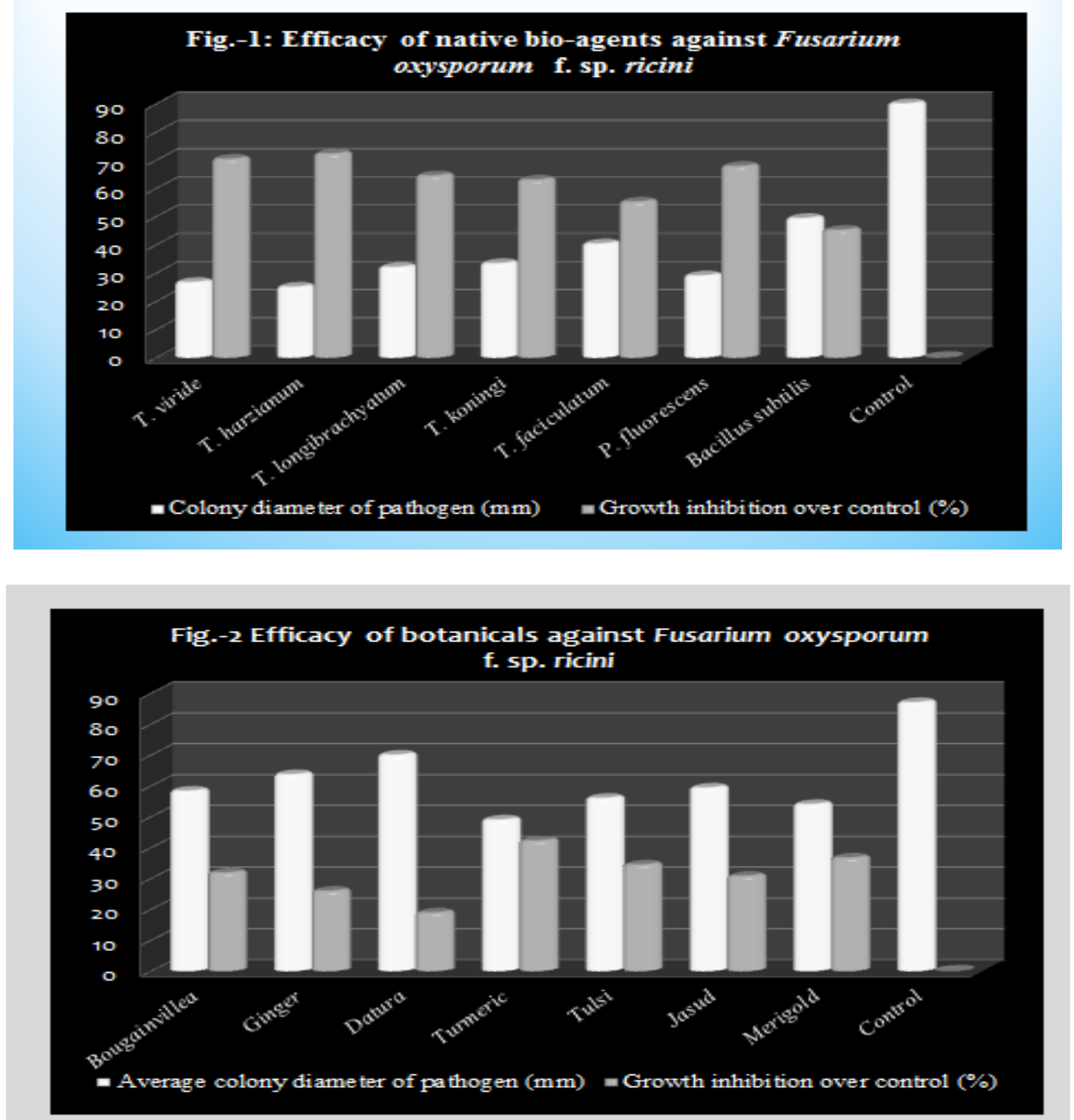

The present studies are in confirmation with those described by earlier worker Chohan and Perveen (2015) studied the effect of botanicals on Fusarium oxysporum f. sp. lycopersici and reported that out of rhizomes extracts tested, Turmeric (Curcuma longa L.) extract was found most inhibitory to Fusarium oxysporum f. sp. lycopersici.

Singh et al., (2014) reported fungitoxic properties of Turmeric, Datura, Ginger, Tulsi and marigold and against growth and of Fusarium oxysporum f. sp. lini. Shalini et al., (2015) tested botanicals, among them turmeric extracts $(5 \%)$ gave 68.05 per cent and ginger extract $(5 \%)$ gave 45.92 per cent inhibition of Fusarium oxysporum f. sp. ricini.

\section{Pot experiment}

The data presented in table 3 revealed that the effects of all the treatments were found significantly superior over control in managing the wilt disease of castor.

Considering disease incident in seed treatment (Trichoderma harzianum @ 6g/kg seed) has lowest $(23.33 \%)$ disease incidence followed by 
(Trichodermaviride@6g/kg seed) (26.67\%), turmeric extract $(33.33 \%)$ and marigold extract $(36.67 \%)$ disease incidence.

The similar results to our present investigation were achieved by Magar et al., (2014) reported that coconut cake, groundnut cake, Trichoderma viride and Trichoderma harzinaum were reduced wilt of check pea by (43.41\%), (31.67\%), (65.77\%) and (65.77\%) respectively.

Meghwal et al., (2014) conducted to assess soil amendments and bioagent. Trichoderma harzianum and T. viride found most effective in reducing the disease of castor wilt caused by Fusarium oxysporum f. sp. ricini.

\section{Acknowledgement}

This work has received support from the help of Professor and Head, Department of Plant Pathology in providing facilities and encouragement to do the work in the Department in Navsari Agricultural University, Navsari, Gujarat, India.

\section{References}

Anonymous, 2015. Annual Progress Report (Castor). AICRP on Castor, Directorate of Oilseeds Research, Hyderabad.

Bliss, C. A., 1934. The method of Probits analysis. Science 79: 39.

Chohan, S., and Perveen, R. 2015. Phytochemical Analysis and Antifungal Efficacy of Rhizome Extracts of various plants against Fusarium Wilt and Root Rot of Tomato. International journal of Agriculture \& Biology, 17:1193-1199.

Dennis, C., and Webster, J. 1971a. Antagonistic properties of species groups of
Trichoderma.Production of non-volatile antibiotics.Trans. British Mycology Society, 57:25-39.

Magar, G. S., Wagh, S. S. and Waghe, K. P. 2014. Management of chickpea wilt Incited by Fusarium oxysporum f. sp. ciceri (Padwick) Snyder and Hansen. Trends in Biosciences, 7(18):2723-2727.

Meghwal, M. L., Jambhulkar, P. P. and Solanki, V. A. 2014. Antogonistic potential of Trichoderma isolates against castor wilt Pathogen ( $F$. oxysporum f. sp. ricini Nanda and Prasad). BIOINFOLET, 11(4 B): 1115 - 1119 .

Patil, V. B., Gawade, D. B., Surywanshi, A. P. and Zagade, S. N. 2015. Biological and fungicide management of chickpea wilt caused by Fusarium oxysporum f. sp.ciceri. The Bioscan, 10(2):685-690.

Shalini, Y., Prasad, M. R., Vidyasagar B. and Giribabu, P. 2015. Botanicals against Fusarium oxysporum f. sp. ricini causing wilt in castor. International Science Congress Association: 15-24.

Singh, J., and Majumdar, V. L. 2001. Efficacy of plant extract against Alternaria alternata- inciting fruit rot of pomegranate (Punica granatum L.). Journal of Mycology and Plant Pathology31: 346-349.

Singh, R. B., Singh, H. K. and Parmar, A. 2014. Evaluation of Mycotoxic Potential of Some Higher Plants against Fusarium oxysporum f. sp. L. causing wilt in Linseed (Linum usitatisimum L.). Journal of Agri Search, 1(1):26-29.

Skidmore, A. M., and Dickinson, C. H. 1976. Colony interaction and hyphal interference between Septoria nodorum and phylloplane fungi. Trans. Br. Mycol. Soc., 66: 57-64.

\section{How to cite this article:}

Vahunia, B., P. Singh, N.Y. Patel and Rathava, A. 2017. Management of Fusarium Wilt of Castor (Ricinus communis L.) Caused by Fusarium oxysporum f. sp. ricini with Antagonist, Botanical Extract and Pot Experiment. Int.J.Curr.Microbiol.App.Sci. 6(9): 390-395. doi: https://doi.org/10.20546/ijcmas.2017.609.048 